\title{
MANAGEMENT OF INVESTMENT PORTFOLIO IDIOSYNCRATIC RISK
}

\author{
Milivoje DAVIDOVIĆ ${ }^{1}$, Vera ZELENOVIĆ ${ }^{2}$ \\ ${ }^{1}$ University of Novi Sad, Faculty of Economics, 24000 Subotica, Segedinski put 9-11, Republic of Serbia. \\ E-mail: milivojed@ef.uns.ac.rs \\ ${ }^{2}$ University of Novi Sad, Faculty of Economics, 24000 Subotica, Segedinski put 9-11, Republic of Serbia.
}

Accepted 30 October, 2012

\begin{abstract}
The investment portfolio is a collection of securities composed according to investor's attitude in terms of yield and risk. It includes total (total) risk that can be decomposed into systematic and idiosyncratic (non-systemic) component. The systematic part of risk is associated with the overall financial market fluctuations, while non-systemic component is associated with the particular investment. Depending on the characteristics of the securities (quality of the issuer), idiosyncratic component is varying in total risk. This paper deals with management of idiosyncratic risk. It is controllable variable that can be reduced by increasing the number of securities in the portfolio - by diversification. The lower correlation between the yields of securities in the portfolio, diversification is more effective. The first part of the paper deals with theoretical concept of idiosyncratic risk reduction through a process of diversification. The second part is devoted to empirical analysis of the impact of increasing the number of securities in the portfolio to reduce idiosyncratic risk. As an example of the financial market we use shares of companies that compose Belex 15. Also, we employ index model (one-factor model) to decompose total risk on systemic and idiosyncratic risk. The conclusion is reserved for research results.
\end{abstract}

Keywords: investment portfolio, systemic risk, idiosyncratic risk, diversification, index model

\section{INTRODUCTION}

Portfolio management is based on technical and fundamental analysis of investment alternatives and making appropriate decisions about taking "long" and "short" investment positions. The investment portfolio is a collection of securities (stocks, bonds, financial derivatives, shares in investment funds) held by individual investors in accordance with the characteristics of the portfolio in the context of risk and return. Bank investment portfolio includes a set of securities hold by bank. Creating an investment portfolio reflects the transformation of the economic environment (under the influence of globalization and deregulation). The banks are in new circumstances faced with increased competition not only within the banking sector, but based on the "overlapping" business there has been a cross-competition between banks and institutional investors. On this basis, the new competitive game can be described as "a struggle of all against all", where profit is the main driving force. The importance of investment portfolio is coming from the importance share of securities in the balance sheet structure of modern banks. Although the credit operations maintain primacy in the asset structure, empirical analysis shows that different types of securities have about $40 \%$ of bank balance sheet share. It is also important to emphasize that creation of the investment portfolio is primarily motivated by profit reasons, but that should not neglect the role of one part of the investment portfolio to maintain an appropriate level of liquidity, which can be determined by qualitative characteristics of securities in the portfolio structure. Portfolio management is based on an active, balanced and passive investment strategy. Investors, in relation to their risk aversion, trade-off between return and risk, are trying to create optimal, efficient, diversified portfolio that is compatible with their investment preferences. They apply a variety of models and portfolio performance evaluation technique - CAPM, APT, Sortino's index, Sharpe's index, Jensen's index and so on, to create an efficient portfolio: on the efficiency frontier and 
the highest level of utility. CAPM model and its variants (the market model) are used to structure the risk on systemic and idiosyncratic risk (nonsystematic risk). Idiosyncratic risk (non-systematic risk) is controllable variable that is controlled by diversification. The effects of diversification are risk reduction, increased average yield and reduce investment portfolio yield variability.

\section{THEORY}

The investment portfolio is weighted with total (total) risk that the modern portfolio theory structured into two components. The first component is a systemic risk. Systemic risk is the product of systemic factors that are inherent to financial market. Systematic (market) risk is constant within the structure of investment portfolio risk: investors must take this part of risk to themselves, accept it as an investment fact. The second component is idiosyncratic risk (nonsystematic risk, specific risk), which is associated with individual securities (Bodie et al., 2010). This part of the risk arising from the performance of securities issuer: the greater the degree of issuer business uncertainty, the higher idiosyncratic risk (non-systematic risk) of securities.

Idiosyncratic risk (non-systematic risk) is the subject of evaluation, monitoring and management in the context of maximizing the criterion function: the maximum yield at an acceptable level of risk or minimal risk with acceptable yield level. Management of idiosyncratic risk (non-systematic risk) means the creation of the investment portfolio, which is characterized by the smallest possible degree of correlation between the securities yield. In such correlation coefficients constellation, increasing the number of securities reduces the idiosyncratic risk (non-systematic risk). Ideally, the portfolio diversification annuls idiosyncratic risk (non-systematic risk), reducing the overall risk of the investment portfolio to the systemic risk level (Figure 1).

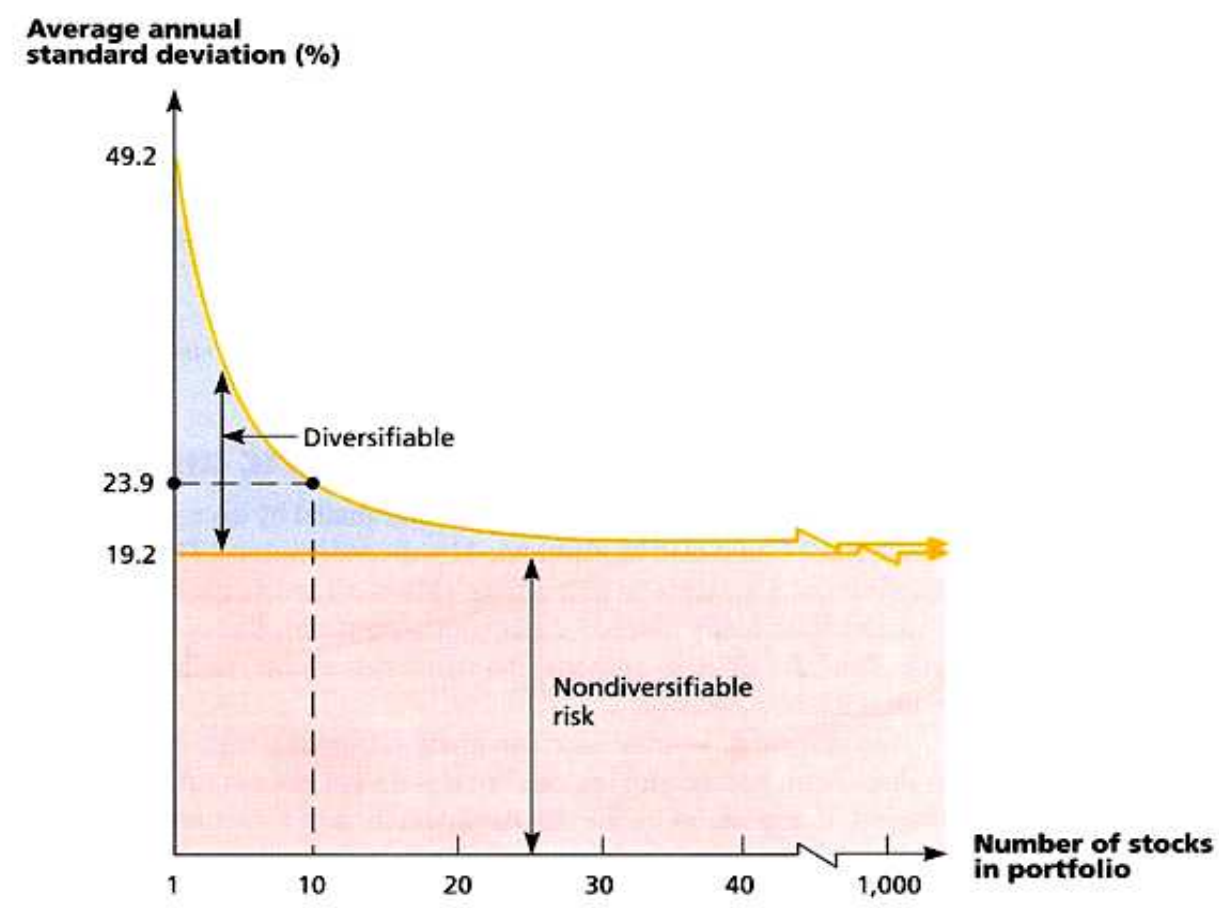

Figure 1: Systemic and idiosyncratic risk (non-systematic risk) (Sutton, 2009)

\begin{abstract}
Diversification does not provide profit different types of securities with different maturity automatically; it also does not irrevocable and different issuers. Efficient diversification guarantee to escape financial losses. In a reduces risk and portfolio return volatility, straightforward strategy that has many complex contributing to the realization of investment goals iterations, but its logic is very simple - increases (Vunjak et al., 2011).
\end{abstract} the number of securities in portfolio, and includes 


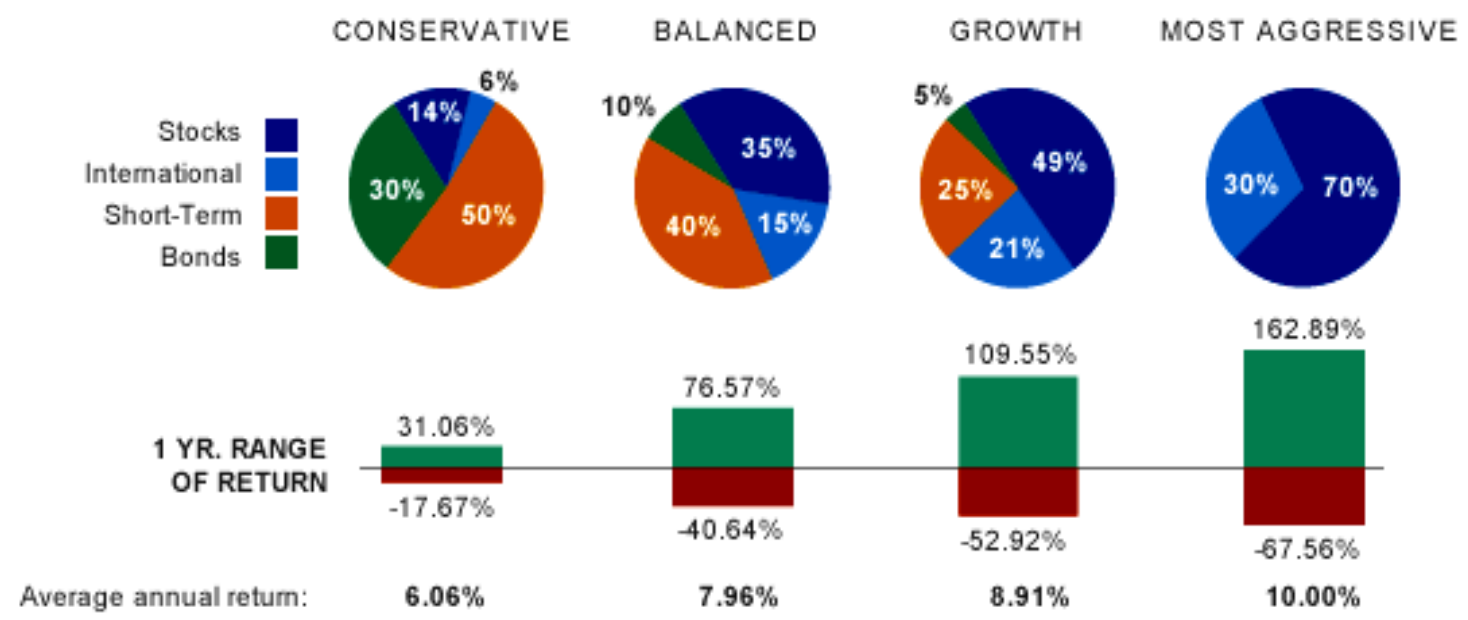

Figure 2: Diversification - returns and risks (Ibbotson Associates, 2011)

Figure 2. ilustrates the conservative, balanced, growth and the most aggressive portfolios as a different combination of stocks (USA), international bonds, short-term securities (money market) and bonds (T-bonds and corporate bonds). In the investment horizon from 1926 to 2010, different portfolio structures realized different average annual returns, returns and losses (including reinvested dividends and other gains). Based on the illustration, it is possible to confirm the return-risk trade-off axiom. The most risky investment portfolio records the widest return range, as well the biggest average annual return. Portfolio structure movements towards conservative structure reduces the profit/loss volume (portfolio volatility decreases) and the average annual return. Thus, it is the matter of investors' preference, i.e. risk appetite. Financial market rewards risk appetite, i.e. it "punishes" risk aversion.

\section{METHODS}

To analyze the effects of diversification, we used a modified version of the CAPM model. It is an index model (market model), which tries to distinguish the impact of additional market index return changes on the additional portfolio yield (systemic risk) in comparison to idiosyncratic risk (non-systematic risk) (specific component of risk). As an expression of idiosyncratic risk (nonsystematic risk), the market model uses the standard deviation of the residuals (standard error of regression). Portfolio structures include some shares that compose BELEX 15, while the index used for calculating the total market yield. For calculating the additional yield, we used the yield on government bonds (A2012) as risk-free investment. The database includes daily cummulative portfolio returns and market index BELEX 15 in 2010-2011. Based on the regression analysis, we established the relation between addional returns of the portfolio and additional returns on the market index itself.

$$
R p a=\alpha+\beta R m+\varepsilon
$$

Where Rpa is additional portfolio return in relation to risk-free investment (rp-rf), $\mathrm{Rm}$ is an additional return on the market index, and $\varepsilon$ is a residual estimation value. We created four portfolios and assume that the investor has no preference in relation to certain share, or that there is a linear distribution of financial resources.

\section{FINDINGS}

Research results can be divided into two categories: first category consists of descriptive statistics (Table 1) for each portfolio (average yield, risk, variability of yields), a second category consists of the results of regression analysis portfolio $\alpha$, portfolio $\beta$, standard error of regression (Figure 3).

Table 1: Descriptive statistics

\begin{tabular}{|c|c|c|c|c|}
\hline & Mean & Variance & St. Dev & Coef. Var. \\
\hline Portfolio 1 & 0.024548 & 0.261517 & 0.511387 & 20968.28 \\
\hline Portfolio 2 & 0.024234 & 0.076066 & 0.275801 & 19751.87 \\
\hline Portfolio 3 & 0.030619 & 0.033791 & 0.183822 & 18082.86 \\
\hline Portfolio 4 & 0.032169 & 0.018954 & 0.137672 & 15570.06 \\
\hline
\end{tabular}

(Source: Author's calculation based on dataa from www.belex.rs) 


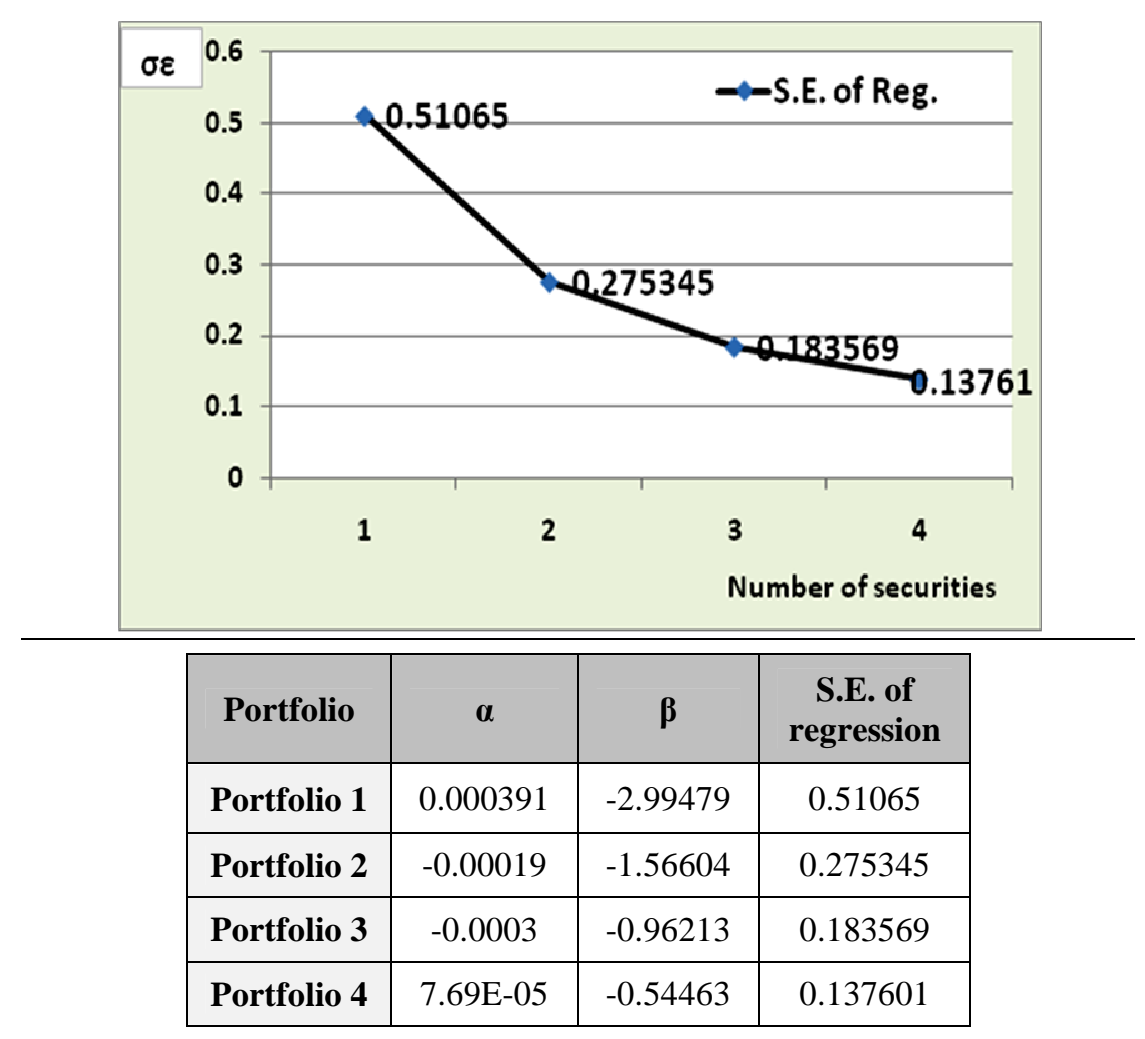

Figure 3: Effects of diversification

(Source: Author's calculation based on data from www.belex.rs)

Analysis of descriptive statistics shows that the increase in the number of securities reduces the standard deviation as a measure of risk, with reducing the variability of yield measured by the coefficient of variation. Also, the positive effects are achieved in the area of average yield, since the average portfolio yield increases with increasing number of securities.

\section{DISCUSSION}

Results of regression analysis are very instructive. Using the index model overall risk of the investment portfolio is segmented on the systemic and non-systemic component, whereby the nonsystemic component is monitored by the standard deviation of the residuals, calculated as the standard error of regression. With the increasing number of securities in the portfolio, idiosyncratic risk (non-systematic risk) is reduced. It shows the downward slope of the curve that symbolizes the standard error of regression. Analysis of the coefficient $\beta$ indicates the degree of systemic risk, or the coefficient of sensitivity to movement portfolio yield in relation to the movement of the market yield. We see that those portfolio structures are countercyclical, and the degree of counter- cyclicality decreases with increasing number of securities.

\section{CONCLUSION}

Modern portfolio theory has emphasized the importance of not only the total risk, but also its structural components: systematic (market) risk and idiosyncratic risk (non-systematic risk, specific risk). As the systematic (market) risk can't be diversified, investment portfolio risk management is based only on the idiosyncratic risk (nonsystematic risk) management. The best way to reduce the idiosyncratic risk (non-systematic risk), and therefore the total portfolio risk, is the portfolio diversification: designing the structure of the portfolio depending on correlation of securities returns. The inclusion of securities with the correlation coefficient closer to zero, you get the highest possible efficiency of the diversification process. Experience shows that diversification reduces the variability of portfolio returns. The greatest diversification effect is achieved by increasing the number of securities in the portfolio from 1 to 10 . After that, the diversification effect is reduced, while increasing the number of securities 
above 20 has not significant effect on reducing of idiosyncratic risk (non-systematic risk).

\section{IMPLICATIONS}

The investment portfolio is a dominant item of the balance sheet of banks in developed countries, while in developing countries consistently growing its balance sheet share. Given the above, management of investment portfolios in the context of the risk-return relationship is imposed as the most important challenge for banks and investors who tend, in the turbulent economic conditions on the global financial markets, to achieve a satisfactory rate of return with the tolerance risk level. Risk management and investment portfolio is essentially based on the idiosyncratic risk (non-systematic risk) management and diversification is imposed as the most powerful investment tool for the realization of this goal. The importance fact is that diversification has its limits: If an investor allocates their funds in any securities that compose a market index, the possibilities of diversification are exhausted.However,the effect of diversification can be increased by investing in securities traded in another country. In this way, the national diversification is replaced by international diversification, with positive effects on reducing of idiosyncratic risk (non-systematic risk).

\section{REFERENCES}

Beogradska berza. (n.d.). Beogradska berza. Retrieved January 15, 2012, from Belex 15:

http://www.belex.rs/trgovanje/indeksi/belex15/dnev ni

Beogradska berza. (n.d.). Beogradska berza. Retrieved January 15, 2012, from A2012 - Vlada Republike Srbije:

http://www.belex.rs/trgovanje/hartija/dnevni/A2012

Bodie, Z., Kane, A., \& Marcus, J. A. (2010). Essentials of Investments (8-th edition). New York: McGrawHill Companies, Inc.

Ibbotson Associates. (2011). Fidelity Investments. Retrieved January 10, 2012, from Diversify Your Portfolio: https://www.fidelity.com/fixed-incomebonds/learn-about-fixed-income-bonds/diversifyyour-portfolio

Sutton, A. (2009, July 24). The Market Oracle. Retrieved May 15, 2010, from Investment Portfolio Diversification \& Risk: http://www.marketoracle.co.uk/Article12274.html

Vunjak, N., Davidović, M., \& Antonijević, T. (2011). Upravljanje investicionim portfoliom u funkciji konkurentske prednosti poslovnih banaka. In N. Janićijević, \& S. Lovreta, Novi metodi marketinga $i$ menadžmenta u podizanju konkurentnosti srpske privrede (pp. 59-74). Beograd: Naučno društvo ekonomista, Ekonomski fakultet Beograd, Ekonomski fakultet Subotica 